\title{
Initial performance of pineapple and utilization of rock phosphate applied in combination with organic compounds to leaf axils ${ }^{1}$
}

\author{
Marihus Altoé Baldotto *, Validoro Bazoni Giro ${ }^{3}$, Lílian Estrela Borges Baldotto ${ }^{2}$, Luciano Pasqualoto Canellas ${ }^{4}$, \\ Ary Carlos Xavier Velloso ${ }^{4}$
}

\begin{abstract}
Rock phosphates have low solubility in water, but good solubility in acid. The use of organic compounds together with these phosphorus sources applied to the basal leaf axils of pineapple can increase the solubility of this phosfate source and increase the Pavailability to the crop. A greenhouse experiment was conducted using Araxá rock phosphate $(10 \mathrm{~g})$ in combination or not with solutions containing increasing concentrations of humic acids $\left(0\right.$ to $40 \mathrm{mmol} \mathrm{L}^{-1}$ of carbon), with or without citric acid $\left(0.005 \mathrm{mmol} \mathrm{L}^{-1}\right)$, applied to basal leaf axils of pineapple cv. Pérola. Growth and nutritional characteristics of aerial plant parts were assessed. Growth rates of aerial parts and $\mathrm{N}, \mathrm{P}, \mathrm{K}, \mathrm{Ca}$ and $\mathrm{Mg}$ contents increased curvilinearly with increasing concentration of carbon in the form of humic acids. Maximum values were found for the concentration of $9.3 \mathrm{mmol} \mathrm{L}^{-1}$ of carbon combined with $0.005 \mathrm{mmol} \mathrm{L}^{-1}$ of citric acid and natural phosphate.
\end{abstract}

Key words: Rock phosphate, humic substances, organic acids, phosphorus solubilization, bioactivity.

\section{RESUMO}

\section{Desempenho inicial do abacaxizeiro e aproveitamento do fosfato natural aplicado com compostos orgânicos nas axilas foliares}

Os fosfatos naturais de rocha apresentam baixa solubilidade em água, sendo mais solúveis em meio ácido. O uso de compostos orgânicos em conjunto com essas fontes de fósforo, aplicados na axila foliar basal dos abacaxizeiros, poderia incrementar a solubilização dessa fonte fosfatada e aumentar a disponibilidade de fósforo para a cultura, tornando-se assim o objetivo do presente estudo. Foi conduzido um experimento em casa de vegetação, com aplicação de fosfato natural de Araxá (10 g), combinado ou não com soluções contendo concentrações crescentes de ácido húmico ( 0 a $40 \mathrm{mmol} \mathrm{L}^{-1}$ de carbono), na presença ou ausência de ácido cítrico $\left(0,005 \mathrm{mmol} \mathrm{L}^{-1}\right)$, na axila basal das folhas de abacaxizeiros. Posteriormente foram medidas as características de crescimento e nutricionais da parte aérea das plantas. Os resultados mostraram que os índices de crescimento da parte aérea e, também, os conteúdos de N, P, K, Ca e Mg aumentaram de forma curvilínea, em razão das concentrações de carbono na forma de ácidos húmicos, sendo os valores máximos observados na concentração de $9,3 \mathrm{mmol} \mathrm{L}^{-1}$ de carbono combinada com ácido cítrico 0,005 $\mathrm{mmol} \mathrm{L}^{-}$ ${ }^{1}$ e fosfato natural.

Palavras-chave: Fosfato de rocha, substâncias húmicas, ácidos orgânicos, solubilização de fósforo, bioatividade.

\footnotetext{
Recebido para publicação em julho de 2009 e aprovado em abril de 2011

${ }^{1}$ Part of the first author's Doctor Science Thesis and part of the second author's Undergraduation Monograph as degree completion requirement for the Course in Agronomy. Work funded by CNPq and FAPERJ.

${ }^{2}$ Agronomist Engineer, Doctor Science. Universidade Federal de Viçosa, Campus de Florestal, 35.690-000, Florestal, MG, Brazil. marihus@ufv.br; lilian.estrela@ufv.br. *Corresponding author: marihus@ufv.br.

${ }^{3}$ Undergraduate Research Fellow. Universidade Estadual do Norte Fluminense Darcy Ribeiro, Soil Laboratory of the Center for Agricultural Science and Technology. Av Alberto Lamego 2000, 28013-602, Campos dos Goytacazes, RJ, Brazil. validoroagro2009@yahoo.com.br.

${ }^{4}$ Agronomist Engineer, Doctor Science, Universidade Estadual do Norte Fluminense Darcy Ribeiro, Soil Laboratory of the Center for Agricultural Science and Technology. Av Alberto Lamego 2000, 28013-602, Campos dos Goytacazes, RJ, Brazil. canellas@uenf.br; velloso@uenf.br.
} 


\section{INTRODUCTION}

Pineapple is a tropical fruit very much appreciated throughout the world. Thailand, Brazil, Philippines, China and India are the main producing countries, amounting to $2.70,2.48,1.83,1.40$, and 1.23 million tones, respectively (FAO, 2010). Natural phosphates provide phosphorus at a lower cost per unit of $\mathrm{P}$, therefore, studies on the use of rock phosphates in pineapple fertilization can make these $\mathrm{P}$ sources economically attractive to the production process (Teixeira et al., 2002).

Notably, the advanced weathering of soils in tropical regions tends to favor the specific adsorption and/or precipitation of phosphates, making this nutrient often limiting for plant development (Leal \& Velloso, 1973; Novais \& Smyth, 1999). Because the soil sink for P tends to be much higher than the plant sink, it is recommended that, whatever the source of soluble phosphorus, management of its use should be localized (Novais \& Smyth, 1999). In pineapple, fertilizers can be applied to the soil and to basal leaf axils (Teixeira et al., 2002).

Although rock phosphates have low solubility in water, it increases with acidity. The use of rock phosphates together with humic and citric acids in basal leaf axils of pineapple, with some leaking into the soil, can enhance $P$ solubility and availability to the crop. The use of natural rock phosphates treated with organic acids of low molecular weight is a common practice to increase phosphorus availability to plants (Kpomblekou \& Tabatabai, 2003; Busato et al., 2005).

Humic acids have been designated as supramolecular aggregates (Piccolo, 2001), forming clusters of heterogeneous organic compounds of low molecular weight, containing predominantly hydrophilic (fulvic acids) or hydrophilic/hydrophobic (humic acids) domains. In natural systems, there is a mixture of these domains. Such aggregates are maintained in solution by hydrogen bonds and hydrophobic interactions which, alone, are weak, but, together, can provide structure to these substances and thus result in a just apparent high molecular mass. When, operationally, ionization is promoted using alkali extractants, both groups are dissolved, whereas acidification provides precipitation of the so-called humic acids only, which are less polar than fulvic acids. Additionally, acidification of humic acids solution with citric acid may influence the structure and conformation of the supramolecular arrangement of these humic substances, with a relative disintegration of these clusters, increasing their reactivity (Piccolo et al. 1996a, b; Piccolo, 2001; Simpson, 2001).

Sposito (2008) emphasizes that humic substances, designated as supramolecules by Piccolo (2001), would have the properties of biomolecules from which they are derived: fragments that form an integral or labile part of the molecular architecture and thus control their conformation, chemical reactivity and bioactivity. In this context, synergistic effects of humic substances on plant growth have been demonstrated and, in a general way, the hypothesis of a hormonal auxinic effect has been proposed. (Nardi et al., 2002; Canellas et al., 2002, 2008a, b; Zandonadi, 2006; and Zandonadi et al., 2007). Baldotto et al. (2009) reported a biostimulating effect from foliar application of humic acids, isolated from vermicompost and filter cake, on pineapple in vitro plantlets during the acclimatization period, resulting in increases in $\mathrm{N}, \mathrm{P}, \mathrm{K}$, $\mathrm{Ca}$, and $\mathrm{Mg}$ contents and growth of aerial parts and root system.

Canellas et al. (2008b) studied the exudation profile of plants treated with humic substances and observed that the presence of citric acid, as well as malic, tartaric, and oxalic acids, increased in exudates of corn roots. Chromatographic analysis of these solutions revealed the presence of low-molecular-weight substances only, indicating the separation of the humic acids aggregate that was initially applied and corroborating previous results obtained by Piccolo et al. (1996a, b), Piccolo (2001) and Simpson (2001). These findings confirm the biomolecules' provider property conceptualized by Sposito (2008) for humic acids, and also as biostimulants, which was as well observed by Nardi et al. (2002), Canellas et al. (2002, 2008a, b) Zandonadi (2006) and Zandonadi et al. (2007) and Canellas et al. (2008a). Canellas et al. (2008b) found that adding citric acid and humic acids to the growth of maize seedlings resulted in higher biostimulation than the control containing only humic substances, in which the concentration of $0.005 \mathrm{mmol} \mathrm{L}^{-1}$ gave the largest increases. These increases were attributed to the relation between the conformation and structure of humic acids, which was included in the conceptual model of Piccolo (2001).

Busato et al. (2005) found that rock phosphate solubilization in solutions containing humic acids increases with decrease in $\mathrm{pH}$ (from 7 to 5). Giro (2008 a, b) reported that the addition of citric acid resulted in increase in Araxá phosphate solubilization with solutions of humic acids, since it is expected a higher exposure of dissociable acid groups (Piccolo, 2001; Sposito, 2008). The results also show that the effect of adding citric acid to the solution of humic acids varies quadratically with the dose, in which $0.005 \mathrm{mmol} \mathrm{L}^{-1}$ gave the maximum response. This concentration of citric acid, in the absence of humic acids, did not provide differences in solubilization of rock phosphates compared with the control treated with distilled water. Thus, the combined application of humic acids and citric acid with natural phosphate rocks to the axils of pineapple can promote greater reactivity of humic 
acids and increased P solubilization. Simultaneously, the combination of these substances can promote physiological stimulation, with auxinic effect, by the release of biomolecules preserved in the supramolecular arrangement of humic acids.

Accordingly, the present study aimed to evaluate the initial performance of pineapple in response to fertilization with Araxá rock phosphate combined with solutions containing increasing concentrations of humic acids ( 0 to $40 \mathrm{mmol} \mathrm{L}^{-1}$ of C) in the presence or absence of citric acid $\left(0.005 \mathrm{mmol} \mathrm{L}^{-1}\right)$ applied to basal leaf axils of pineapple cv. Pérola.

\section{MATERIALAND METHODS}

A greenhouse experiment was conducted at the Norte Fluminense Darcy Ribeiro University, UENF, Campos dos Goytacazes, RJ, Brazil. The treatments were arranged in a $3+3+1+1$ Baconian matrix, including: Araxá rock phosphate combined with three concentrations of humic acids, with addition or not of citric acid, Araxá rock phosphate only, and control (Table 1).

The experiment was conducted in a randomized block design with six replicates. Fertilization, irrigation and other factors were controlled and kept constant in all treatments, according to recommendations by Novais et al. (1991).

The experimental unit consisted of a $10 \mathrm{dm}^{3}$ polyethylene pot, filled with B horizon of a Yellow Latosol from Campos dos Goytacazes, described and chemically characterized at EMBRAPA (1980), with the following features: $\mathrm{C}=0.30 \mathrm{~g} \mathrm{~kg}^{-1} ; \mathrm{pH}\left(\mathrm{H}_{2} \mathrm{O}\right)=4.8 ; \mathrm{P}($ Mehlich- 1$)=$ $6.0 \mathrm{mg} \mathrm{dm}^{-3} ; \mathrm{K}^{+}=5.0 \mathrm{mg} \mathrm{dm}^{-3} ; \mathrm{Ca}^{2+}=0.71 \mathrm{cmolc} \mathrm{dm}^{-3}$; $\mathrm{Mg}^{2+}=0.25 \mathrm{cmolc} \mathrm{dm}^{-3} ; \mathrm{Al}^{3+}=1.33 \mathrm{cmolc} \mathrm{dm}^{-3}$, and $\mathrm{H}+\mathrm{Al}$ $=4.42 \mathrm{cmolc} \mathrm{dm}^{-3}$, among other attributes.

Of the eight treatments, seven received $10 \mathrm{~g}$ of rock phosphate (Araxá phosphate), with total $\mathrm{P}$ concentration equivalent to $240 \mathrm{~g} \mathrm{~kg}^{-1}$ of $\mathrm{P}_{2} \mathrm{O}_{5}$ and one was used as

Table 1. Experimental design. Treatments arranged according to a $3+3+1+1$ factorial Baconian matrix.

\begin{tabular}{|c|c|c|c|}
\hline \multirow{3}{*}{ Treatment $^{(1)}$} & \multicolumn{3}{|c|}{ Factors } \\
\hline & $\mathrm{C}_{\mathrm{HA}}{ }^{(2)}$ & CA & NF \\
\hline & \multicolumn{2}{|c|}{$\mathrm{mmol} \mathrm{L}^{-1}$} & $-g-$ \\
\hline$(-)$ & 0 & 0 & 0 \\
\hline $\mathrm{NF}$ & 0 & 0 & 10 \\
\hline $\mathrm{NF}+\mathrm{HA}(10)$ & 10 & 0 & 10 \\
\hline $\mathrm{NF}+\mathrm{HA}(20)$ & 20 & 0 & 10 \\
\hline $\mathrm{NF}+\mathrm{HA}(40)$ & 40 & 0 & 10 \\
\hline $\mathrm{NF}+\mathrm{HA}(10)+\mathrm{CA}$ & 10 & 0.005 & 10 \\
\hline $\mathrm{NF}+\mathrm{HA}(20)+\mathrm{CA}$ & 20 & 0.005 & 10 \\
\hline $\mathrm{NF}+\mathrm{HA}(40)+\mathrm{CA}$ & 40 & 0.005 & 10 \\
\hline
\end{tabular}

(1) Treatments: $(-)=$ control; $\mathrm{NF}=$ Araxá natural phosphate; HA = humic acid, $\mathrm{CA}=$ citric acid. ${ }^{\text {(2) }} \mathrm{C}_{\mathrm{HA}}=$ carbon in the form of vermicompost-derived humic acids. control. The plants were treated with solutions containing concentrations of 10,20 and $40 \mathrm{mmol} \mathrm{L}^{-1}$ of $\mathrm{C}$ in the form of vermicompost-derived humic acids (HA) (Baldotto et al., 2009), with approximately $5 \mathrm{~g} \mathrm{~kg}^{-1}$ of $\mathrm{C}$, combined or not with citric acid $(\mathrm{CA})\left(\mathrm{C}_{6} \mathrm{H}_{8} \mathrm{O}_{7} \cdot \mathrm{H}_{2} \mathrm{O}\right)$ at a concentration of $0.005 \mathrm{mmol} \mathrm{L}^{-1}$ (Canellas et al., 2008b). The vermicompost-derived humic acid was previously isolated and characterized by Baldotto et al. (2007) and citric acid was a pure analytical reagent. Slips of pineapple (Ananas comosus (L) Merril) cultivar Pérola, were previously immersed in solutions containing organic acids of each treatment for 24 hours (Table 1). Immediately after planting, rock phosphate was applied to the axils, and 100 $\mathrm{mL}$ of the same solutions of organic acids were applied to the basal leaf axils.

At 45 days after planting, the following variables were measured: plant height ( $\mathrm{PH})$; length of the "D" leaf, which is inserted at an angle of 45 degrees to the stem, between the ground level and an imaginary axis through the center of the plant (LD); width of the middle one-third of "D" leaf (WD); rosette diameter (RD) and diameter at base (BD), using a caliper; and leaf number (LN). Leaf area (LA) was estimated by image analysis using a 3100 LI-COR meter.

Plants were cut close to ground level and aerial plant part was weighed to obtain fresh matter (FM) and then dried in an forced-air oven at $60^{\circ} \mathrm{C}$ to a constant weight to determine dry matter (DM). DM was subjected to sulfuric digestion combined with hydrogen peroxide to determine total N, P, K, Ca and Mg. N was determined by the method of Nessler. P content was obtained by molecular absorption spectrophotometry (colorimetry) after reaction with vitamin $\mathrm{C}$ and ammonium molybdate, at $725 \mathrm{~nm}$; $\mathrm{K}$ was determined by flame photometry; and $\mathrm{Ca}$ and $\mathrm{Mg}$ were measured by atomic absorption spectrophotometry. All determinations were performed according to the usual methods for pineapple crop of the Mineral Nutrition Sector at the Plant Science Laboratory, UENF (Ramos, 2006). Nutrient contents were calculated by multiplying the dry weight of aerial part by the nutrient content.

Data were examined by analysis of variance, and the effects of qualitative factors were decomposed in mean contrasts, according to Alvarez V. \& Alvarez (2006). Table 2 shows the coefficients of the contrasts studied.

Quantitative factors were studied by regression analysis. Regression equations were adjusted between the mean variables and the humic acid concentrations, combined with phosphate, using or not citric acid. The F test was applied to the decomposed factors at 10,5 and $1 \%$ probability level (Steel \& Torrie, 1960). Models from the regression analysis were selected when determination coefficients were above $0.60\left(\mathrm{R}^{2}>0.60\right)$. The regression equations for pineapple dry matter were used to determine the concentrations of maximum physical efficiency 
Table 2. Coefficients for treatment contrasts.

\begin{tabular}{|c|c|c|c|c|c|c|c|}
\hline \multirow{2}{*}{ Treatment $^{(1)}$} & \multicolumn{7}{|c|}{ Contrasts $^{(2)}$} \\
\hline & C1 & $\mathrm{C2}$ & C3 & $\mathrm{C4}$ & C5 & C6 & C7 \\
\hline$(-)$ & -7 & -1 & -3 & -3 & 0 & 0 & 0 \\
\hline $\mathrm{NF}$ & +1 & +1 & 0 & 0 & -3 & -3 & 0 \\
\hline NF+HA(10) & +1 & 0 & +1 & 0 & +1 & 0 & -1 \\
\hline $\mathrm{NF}+\mathrm{HA}(20)$ & +1 & 0 & +1 & 0 & +1 & 0 & -1 \\
\hline $\mathrm{NF}+\mathrm{HA}(40)$ & +1 & 0 & +1 & 0 & +1 & 0 & -1 \\
\hline $\mathrm{NF}+\mathrm{HA}(10)+\mathrm{CA}$ & +1 & 0 & 0 & +1 & 0 & +1 & +1 \\
\hline $\mathrm{NF}+\mathrm{HA}(20)+\mathrm{CA}$ & +1 & 0 & 0 & +1 & 0 & +1 & +1 \\
\hline $\mathrm{NF}+\mathrm{HA}(40)+\mathrm{CA}$ & +1 & 0 & 0 & +1 & 0 & +1 & +1 \\
\hline
\end{tabular}

(1) Treatments: $(-)=$ control; $\mathrm{NF}=$ Araxá natural phosphate; $\mathrm{HA}=$ humic acid, $\mathrm{CA}=$ citric acid. ${ }^{(2)}$ Contrasts: $\mathrm{C} 1=$ control vs. factorial; $\mathrm{C} 2$ = control vs. NF; C3 = control vs. $\mathrm{NF}+\mathrm{HA} ; \mathrm{C} 4=$ control vs. $\mathrm{NF}+\mathrm{HA}+\mathrm{CA} ; \mathrm{C} 5=\mathrm{NF}$ vs. $\mathrm{NF}+\mathrm{HA} ; \mathrm{C} 6=\mathrm{NF}$ vs. $\mathrm{NF}+\mathrm{HA}+\mathrm{CA}$, and $\mathrm{C} 7$ $=\mathrm{NF}+\mathrm{HA}$ vs. $\mathrm{NF}+\mathrm{HA}+\mathrm{CA}$.

(MPE). The regression equations for the other variables were used to calculate their MPE values for maximum plant dry matter.

\section{RESULTS}

\section{Growth characteristics}

Overall, there were effects of treatments on growth and mass accumulation of pineapple compared with the control (Tables 3 and 4), except for leaf number (LN). For plant height $(\mathrm{PH})$, length and width of "D" leaf (LD and WD), rosette and base diameters (RD and BD), fresh and dry matters, and leaf area (FM, DM and FA) of aerial parts, the increases were 16, 9, 12, 17, 17, 32, 29 and 32\% respectively (Table 4).

The decomposition of treatment effects showed that there was no significant DM increase in the combination of phosphate and humic acids compared with the control (control versus NF + HA), but with addition of citric acid, the effect was significant and resulted in a $40 \% \mathrm{DM}$ increase over the control (control versus $\mathrm{NF}+\mathrm{HA}+\mathrm{CA}$ ) and approximately $16 \% \mathrm{DM}$ over the combination phosphate and humic acids (NF + HA versus NF + HA + CA) (Table 4). For leaf area, the effect of the combination of phosphate and humic acids was positive and $25 \%$ over the control (control versus NF + HA), increasing to $42 \%$ with addition of citric acid (control versus NF + HA + CA).

The use of phosphate with humic acids was not superior to phosphate alone (NF versus NF + HA), but in the presence of citric acid (NF versus $\mathrm{NF}+\mathrm{HA}+\mathrm{CA}$ ) the effect was 19\% higher. The comparison of phosphate rock combined with humic acids with or without citric acid (HA $+\mathrm{NF}$ versus $\mathrm{NF}+\mathrm{HA}+\mathrm{CA}$ ) showed that the use of the latter increased in $14 \%$ the pineapple leaf area (Table 4).

In general, the response of pineapple growth characteristics showed curvilinear increases at squared root or quadratic rates as a function of the increasing concentrations of humic acids combined with rock

Table 3. Growth characteristics of the aerial part of pineapple cv. Pérola in response to application of rock phosphate combined or not with humic acids, with or without citric acid

\begin{tabular}{|c|c|c|c|c|c|c|c|c|c|}
\hline \multirow[t]{3}{*}{ Treatment ${ }^{(1)}$} & \multicolumn{9}{|c|}{ Growth characteristics ${ }^{(2)}$} \\
\hline & \multirow{2}{*}{$\begin{array}{c}\text { LN } \\
\text { g/plant }\end{array}$} & PH & LD & WD & RD & \multirow{2}{*}{$\begin{array}{l}\text { BD } \\
\mathrm{mm}\end{array}$} & FM & DM & \multirow{2}{*}{$\frac{\text { LA }}{\mathrm{cm}^{2} / \mathrm{pl}}$} \\
\hline & & \multicolumn{4}{|c|}{$\mathrm{cm}$} & & \multicolumn{2}{|c|}{$\mathrm{g} / \mathrm{plant}$} & \\
\hline$(-)$ & 16 & 17.00 & 19.88 & 2.22 & 19.57 & 23.00 & 51.32 & 8.77 & 540.20 \\
\hline $\mathrm{NF}$ & 16 & 19.33 & 21.40 & 2.42 & 22.25 & 28.47 & 62.37 & 10.72 & 644.05 \\
\hline $\mathrm{NF}+\mathrm{HA}(10)$ & 19 & 20.50 & 22.12 & 2.38 & 22.68 & 27.23 & 69.27 & 10.75 & 725.73 \\
\hline $\mathrm{NF}+\mathrm{HA}(20)$ & 17 & 18.33 & 20.75 & 2.25 & 22.83 & 23.09 & 51.67 & 9.02 & 613.57 \\
\hline $\mathrm{NF}+\mathrm{HA}(40)$ & 17 & 19.42 & 21.17 & 2.45 & 23.08 & 24.67 & 62.27 & 11.57 & 679.14 \\
\hline $\mathrm{NF}+\mathrm{HA}(10)+\mathrm{CA}$ & 20 & 22.53 & 23.37 & 2.70 & 24.87 & 30.73 & 93.93 & 14.17 & 913.47 \\
\hline $\mathrm{NF}+\mathrm{HA}(20)+\mathrm{CA}$ & 18 & 19.25 & 21.20 & 2.55 & 24.58 & 26.36 & 66.82 & 12.30 & 713.72 \\
\hline $\mathrm{NF}+\mathrm{HA}(40)+\mathrm{CA}$ & 17 & 18.58 & 21.22 & 2.57 & 20.08 & 28.46 & 70.37 & 10.68 & 707.71 \\
\hline Mean NF+HA & 17 & 19.42 & 21.35 & 2.36 & 22.86 & 25.00 & 61.07 & 10.45 & 672.81 \\
\hline Mean $\mathrm{NF}+\mathrm{HA}+\mathrm{CA}$ & 18 & 20.12 & 21.93 & 2.61 & 23.18 & 28.52 & 77.04 & 12.38 & 778.30 \\
\hline
\end{tabular}

(1) Treatment: $(-)=$ control; HA (10) $=$ vermicompost-derived humic acids at $10 \mathrm{mmol} \mathrm{L}^{-1}$ of $\mathrm{C}$; HA $(20)=$ vermicompost-derived humic acids at $20 \mathrm{mmol} \mathrm{L}^{-1}$ of $\mathrm{C}$; $\mathrm{HA}(40)=$ vermicompost-derived humic acids at $40 \mathrm{mmol} \mathrm{L} \mathrm{L}^{-1}$ of $\mathrm{C} ; \mathrm{CA}=$ citric acid, and $\mathrm{NF}=$ rock phosphate. ${ }^{(2)}$ Growth characteristics: $\mathrm{LN}=$ leaf number; $\mathrm{PH}=$ plant height; $\mathrm{LD}=$ length of $\mathrm{D}$ leaf; $\mathrm{WD}=$ width of $\mathrm{D}$ leaf; $\mathrm{RD}=$ rosette diameter; $\mathrm{BD}=$ base diameter; and FM, DM and LA = fresh matter, dry matter and leaf area of pineapple aerial parts, respectively. 
Table 4. Mean contrasts, relative increments, mean square error (MSE) and coefficient of variation (CV) for growth characteristics of the aerial part of pineapple cv. Pérola in response to application of rock phosphate combined or not with humic acids, with or without citric acid

\begin{tabular}{|c|c|c|c|c|c|c|c|c|c|c|}
\hline \multirow[t]{3}{*}{ Comparison ${ }^{(1)}$} & \multirow[t]{3}{*}{ D.F. } & \multicolumn{9}{|c|}{$\begin{array}{l}\text { Mean contrasts for growth characteristics }{ }^{(2)} \\
\qquad\left(\text { Relative increments }{ }^{(3)}\right)\end{array}$} \\
\hline & & $\mathbf{L N}$ & PH & LD & WD & RD & \multirow{2}{*}{ BD } & FM & DM & \multirow{2}{*}{$\frac{\text { LA }}{\mathrm{cm}^{2} / \text { plant }}$} \\
\hline & & $\mathrm{g} /$ plant & \multicolumn{4}{|c|}{$\mathrm{cm}$} & & \multicolumn{2}{|c|}{ g/plant } & \\
\hline (-) vs. Factorial & 1 & $\begin{array}{c}0.55 \\
(10)\end{array}$ & $\begin{array}{c}2.71^{* *} \\
(16)\end{array}$ & $\begin{array}{c}1.72 * \\
(9)\end{array}$ & $\begin{array}{r}0.26^{*} \\
(12)\end{array}$ & $\begin{array}{r}3.35^{*} \\
(17)\end{array}$ & $\begin{array}{r}4.00 * \\
(17)\end{array}$ & $\begin{array}{r}16.31^{\circ} \\
(32)\end{array}$ & $\begin{array}{r}2.49^{\circ} \\
(29)\end{array}$ & $\begin{array}{l}169^{*} \\
(32)\end{array}$ \\
\hline (-) vs. NF & 1 & $\begin{array}{l}0.17 \\
\quad(1)\end{array}$ & $\begin{array}{r}2.33^{\circ} \\
(14)\end{array}$ & $\begin{array}{r}1.52 \\
(8)\end{array}$ & $\begin{array}{r}0.20 \\
(9)\end{array}$ & $\begin{array}{r}2.68 \\
(14)\end{array}$ & $\begin{array}{r}5.47 * \\
(24)\end{array}$ & $\begin{array}{r}11.14 \\
(22)\end{array}$ & $\begin{array}{r}1.99 \\
(23)\end{array}$ & $\begin{array}{l}106 \\
(20)\end{array}$ \\
\hline (-) vs. NF+HA & 1 & $\begin{array}{r}1.28 \\
(8)\end{array}$ & $\begin{array}{r}2.42 * \\
(14)\end{array}$ & $\begin{array}{r}1.46^{\circ} \\
(7)\end{array}$ & $\begin{array}{l}0.14 \\
(7)\end{array}$ & $\begin{array}{r}3.30^{\circ} \\
(17)\end{array}$ & $\begin{array}{r}2.00 \\
(9)\end{array}$ & $\begin{array}{r}10.25 \\
(20)\end{array}$ & $\begin{array}{r}1.75 \\
(20)\end{array}$ & $\begin{array}{l}135^{\circ} \\
(25)\end{array}$ \\
\hline (-) vs. $\mathrm{NF}+\mathrm{HA}+\mathrm{CA}$ & 1 & $\begin{array}{r}2.28 * \\
(14)\end{array}$ & $\begin{array}{c}3.12 * * \\
(18)\end{array}$ & $\begin{array}{r}2.04 * \\
(10)\end{array}$ & $\begin{array}{c}0.39 * * \\
(18)\end{array}$ & $\begin{array}{c}3.61 * \\
(18)\end{array}$ & $\begin{array}{r}5.52 * \\
(24)\end{array}$ & $\begin{array}{c}24.09 * * \\
(48)\end{array}$ & $\begin{array}{r}3.41 * \\
(40)\end{array}$ & $\begin{array}{l}225 * * \\
(42)\end{array}$ \\
\hline NF vs. NF+HA & 1 & $\begin{array}{r}1.11 \\
(7)\end{array}$ & $\begin{array}{l}0.08 \\
(0.4)\end{array}$ & $\begin{array}{r}-0.06 \\
(0.3)\end{array}$ & $\begin{array}{r}-0.06 \\
(2)\end{array}$ & $\begin{array}{r}0.62 \\
(3)\end{array}$ & $\begin{array}{r}-3.47 \\
(14)\end{array}$ & $\begin{array}{r}-0.88 \\
\quad(1)\end{array}$ & $\begin{array}{r}-0.25 \\
\quad(2)\end{array}$ & $\begin{array}{l}29 \\
(5)\end{array}$ \\
\hline $\mathrm{NF}$ vs. $\mathrm{NF}+\mathrm{HA}+\mathrm{CA}$ & 1 & $\begin{array}{c}2.11 * \\
(13)\end{array}$ & $\begin{array}{r}0.79 \\
(4)\end{array}$ & $\begin{array}{r}0.53 \\
(2)\end{array}$ & $\begin{array}{r}0.19 \\
\quad(8)\end{array}$ & $\begin{array}{r}0.93 \\
(4)\end{array}$ & $\begin{array}{r}0.05 \\
\quad(0)\end{array}$ & $\begin{array}{r}12.95 \\
(21)\end{array}$ & $\begin{array}{r}1.41 \\
(13)\end{array}$ & $\begin{array}{l}119^{\circ} \\
(19)\end{array}$ \\
\hline $\mathrm{NF}+\mathrm{HA}$ vs. $\mathrm{NF}+\mathrm{HA}+\mathrm{CA}$ & 1 & $\begin{array}{r}1.00 \\
(6)\end{array}$ & $\begin{array}{l}0.71 \\
\quad(4)\end{array}$ & $\begin{array}{r}0.58 \\
(3)\end{array}$ & $\begin{array}{c}0.24 * * \\
(10)\end{array}$ & $\begin{array}{r}0.31 \\
\quad(1)\end{array}$ & $\begin{array}{r}3.52 \\
(14)\end{array}$ & $\begin{array}{r}13.83^{*} \\
(23)\end{array}$ & $\begin{array}{r}1.66^{\circ} \\
(16)\end{array}$ & $\begin{array}{l}90 * \\
(14)\end{array}$ \\
\hline MSE & 38 & 5.00 & 4.66 & 3.22 & 0.07 & 14.13 & 20.31 & 0.27 & 0.01 & 23 \\
\hline $\mathrm{CV}(\%)$ & & 12.77 & 11.14 & 8.38 & 10.58 & 16.71 & 17.01 & 14.26 & 16.76 & 12 \\
\hline
\end{tabular}

(1) Comparison: $(-)$ = control; $\mathrm{HA}=$ vermicompost-derived humic acids; $\mathrm{CA}=$ citric acid; and $\mathrm{NF}=$ rock phosphate. ${ }^{(2)}$ Growth characteristics: $\mathrm{LN}=$ leaf number; $\mathrm{PH}=$ plant height; $\mathrm{LD}=$ length of $\mathrm{D}$ leaf; $\mathrm{WD}=$ width of $\mathrm{D}$ leaf; $\mathrm{RD}=$ rosette diameter; $\mathrm{BD}=$ base diameter; and $\mathrm{FM}$, $\mathrm{DM}$ and $\mathrm{LA}=$ fresh matter, dry matter and leaf area of pineapple aerial parts, respectively. ${ }^{(3)}$ Relative increments: $100(\mathrm{x}-\mathrm{y}) / \mathrm{y}$, where $\mathrm{x}$ $=$ mean of treatment with the highest value and $\mathrm{y}=$ mean of treatment with the lowest value. ${ }^{\circ},{ }^{*}$ and $* *=$ significant at 10,5 and $1 \%$ probability levels, respectively.

Table 5. Regression equations for growth characteristics of the aerial part of pineapple cv. Pérola as a function of concentrations of humic acids (HA) combined with natural phosphate (NF), with or without citric acid (CA)

\begin{tabular}{|c|c|c|c|}
\hline Variable $^{(1)}$ & Decomposition $^{(2)}$ & Regression equation & $\mathbf{R}^{2}$ \\
\hline \multirow[t]{2}{*}{$\mathrm{LN}$} & $\mathrm{NF}+\mathrm{HA}$ & $\hat{y}=\bar{y}=17.17$ & \\
\hline & $\mathrm{NF}+\mathrm{HA}+\mathrm{CA}$ & $\hat{y}=16.40+1.63 * x^{0.5}-0.239 x$ & 0.898 \\
\hline \multirow[t]{2}{*}{$\mathrm{PH}$} & $\mathrm{NF}+\mathrm{HA}$ & $\hat{y}=\bar{y}=19.40$ & \\
\hline & $\mathrm{NF}+\mathrm{HA}+\mathrm{CA}$ & $\hat{\mathrm{y}}=\overline{\mathrm{y}}=19.93$ & \\
\hline \multirow[t]{2}{*}{ LD } & $\mathrm{NF}+\mathrm{HA}$ & $\hat{y}=\bar{y}=21.36$ & \\
\hline & $\mathrm{NF}+\mathrm{HA}+\mathrm{CA}$ & $\hat{\mathrm{y}}=\overline{\mathrm{y}}=21.80$ & \\
\hline \multirow[t]{2}{*}{ WD } & $\mathrm{NF}+\mathrm{HA}$ & $\hat{y}=2.44-0.0147 x+0.00037^{\circ} x^{2}$ & 0.768 \\
\hline & $\mathrm{NF}+\mathrm{HA}+\mathrm{CA}$ & $\hat{\mathrm{y}}=2.43+0.112^{(\mathrm{P}<0.15)} \mathrm{x}^{0.5}-0.0015 \mathrm{x}$ & 0.707 \\
\hline \multirow[t]{2}{*}{$\mathrm{RD}$} & $\mathrm{NF}+\mathrm{HA}$ & $\hat{y}=22.25+0.136 * x^{0.5}-0.0008 x$ & 0.999 \\
\hline & $\mathrm{NF}+\mathrm{HA}+\mathrm{CA}$ & $\hat{y}=22.38-0.30 x+0.0091^{\circ} x^{2}$ & 0.986 \\
\hline \multirow[t]{2}{*}{$\mathrm{BD}$} & $\mathrm{NF}+\mathrm{HA}$ & $\hat{y}=28.97-0.37 x+0.0066^{(\mathrm{P}<0.12)} \mathrm{x}^{2}$ & 0.823 \\
\hline & $\mathrm{NF}+\mathrm{HA}$ & $\hat{\mathrm{y}}=\overline{\mathrm{y}}=28.50$ & \\
\hline \multirow[t]{2}{*}{ FM } & $\mathrm{NF}+\mathrm{HA}+\mathrm{CA}$ & $\hat{y}=\bar{y}=60.86$ & \\
\hline & $\mathrm{NF}+\mathrm{HA}$ & $\hat{\mathrm{y}}=\overline{\mathrm{y}}=71.23$ & \\
\hline \multirow[t]{2}{*}{$\mathrm{DM}$} & $\mathrm{NF}+\mathrm{HA}+\mathrm{CA}$ & $\hat{y}=11.02-0.150 x+0.004^{\circ} x^{2}$ & 0.662 \\
\hline & $\mathrm{NF}+\mathrm{HA}$ & $\hat{y}=10.70+1.65^{*} x^{0.5}-0.27 x$ & 0.879 \\
\hline \multirow[t]{2}{*}{ LA } & $\mathrm{NF}+\mathrm{HA}+\mathrm{CA}$ & $\hat{y}=\bar{y}=661.22$ & \\
\hline & $\mathrm{NF}+\mathrm{HA}$ & $\hat{y}=650.15+102.65^{(P<0.18)} x^{0.5}-15.95 x$ & 0.619 \\
\hline
\end{tabular}

(1) Variable: $\mathrm{LN}=$ leaf number; $\mathrm{PH}=$ plant height $(\mathrm{cm}) ; \mathrm{LD}=$ length of $\mathrm{D}$ leaf $(\mathrm{cm})$; WD = width of D leaf $(\mathrm{cm})$; RD = rosette diameter $(\mathrm{cm}) ; \mathrm{BD}=$ base diameter $(\mathrm{mm}) ; \mathrm{FM}, \mathrm{DM}$ and LA = fresh matter (g/plant), dry matter (g/plant) and leaf area $\left(\mathrm{cm}^{2} / \mathrm{plant}\right)$ of aerial part, respectively. ${ }^{(2)}$ Decomposition: NF = rock phosphate; HA = vermicompost-derived humic acids; $\mathrm{CA}=$ citric acid. ${ }^{(\mathrm{P}), \circ}$ and $*=$ significant at $\mathrm{P}, 10$ and $5 \%$ probability levels. 
phosphate, with or without citric acid, respectively (Table 5).

The maximum DM accumulation in the aerial parts was $9.6 \mathrm{~g}$ per plant for the combination phosphate and humic acids $(\mathrm{NF}+\mathrm{HA})$ and $13.2 \mathrm{~g}$ per plant for the same combination plus citric acid (NF+ HA + CA) (Table 6). The results also show that the greatest DM accumulation with citric acid occurred at much lower concentrations of humic acids: $9.3 \mathrm{mmol} \mathrm{L}^{-1}$ of $\mathrm{C}$ in the form of humic acids relative to $18.8 \mathrm{mmol} \mathrm{L}^{-1}$ of $\mathrm{C}$ for treatments without citric acid.

Table 7 shows the variables of pineapple aerial parts at the concentration of humic acids of maximum physical efficiency (peak of dry matter). These values were estimated by assigning to the independent variable (x) of the regression equations, in Table 5, the concentrations of Table 6 . These results are the expression of the other pineapple growth characteristics for the two main treatment groups, i.e., phosphate combined with humic acids, with and without citric acid, when the dry matter was highest for these treatments. Hence, it allows the comparison of other plant characteristics in response to

Table 6. Points of maximum dry matter (DM) of the aerial part of pineapple cv. Pérola as a function of concentrations of humic acids (HA) combined with rock phosphate (NF), with or without citric acid (CA)

\begin{tabular}{lcc}
\hline \multirow{2}{*}{ Treatment } & \multicolumn{2}{c}{ Point of $^{\text {maximum }}{ }^{(\mathbf{1})}$} \\
\cline { 2 - 3 } & $\begin{array}{c}\text { DM } \\
\text { g/plant }\end{array}$ & $\begin{array}{c}\text { HA concentration } \\
\text { mmol L }^{-1} \text { of } \mathbf{C}\end{array}$ \\
\hline NF+HA & 9.6 & 8.8 \\
NF+HA+CA & 13.2 & 9.3 \\
\hline
\end{tabular}

(1) Generated by the first derivative of the regression equation.

Table 7. Values of growth characteristics of the aerial part of pineapple cv. Pérola for the treatments rock phosphate combined with humic acids with citric acid (NF + HA) or without citric acid (NF + HA + CA), based on the concentration of maximum physical efficiency (MPE) estimated for the point of highest dry matter, or means, when models showed correlation coefficients below 0.60

\begin{tabular}{lrc}
\hline \multirow{2}{*}{ Characteristic $^{(1)}$} & \multicolumn{2}{c}{ Values for the MPE concentration } \\
\cline { 2 - 3 } & NF+HA & NF+HA+CA \\
\hline LN & 17.17 & 19.15 \\
PH (cm) & 19.40 & 19.93 \\
LD (cm) & 21.36 & 21.80 \\
WD (cm) & 2.29 & 2.76 \\
RD (cm) & 22.82 & 20.38 \\
BD (mm) & 24.35 & 28.50 \\
FM (g/plant) & 60.86 & 71.23 \\
LA (cm²/plant) & 661.22 & 777.56 \\
\hline
\end{tabular}

(1) Characteristic: $\mathrm{LN}=$ leaf number; $\mathrm{PH}=$ plant height; $\mathrm{LD}=$ length of $\mathrm{D}$ leaf; $\mathrm{WD}=$ width of $\mathrm{D}$ leaf; $\mathrm{RD}=$ rosette diameter; $\mathrm{BD}=$ base diameter; and FM, DM and LA = fresh matter, dry matter and leaf area of pineapple aerial parts, respectively. both treatments, in the condition of the highest reserve accumulation by pineapple plants (Table 7).

\section{Nutritional composition}

$\mathrm{N}, \mathrm{P}, \mathrm{K}, \mathrm{Ca}$ and $\mathrm{Mg}$ contents in the pineapple aerial parts varied significantly in response to application of phosphate rock combined with humic acids with or without citric acid (Tables 8 and 9).

Table 9 shows increases in the absorption and accumulation of all nutrients for the treatments compared with the control (control versus factorial). For P, the focus of this study, for example, the mean of the treatments was $3.09 \mathrm{mg}$ per plant, $43 \%$ greater than the control. The effect of the combination phosphate with humic acids and citric acid compared with the control (control versus NF + HA + CA) was higher than that obtained with natural phosphate alone (control versus NF) or rock phosphate and humic acids (control versus NF + HA), achieving increases of $4.14 \mathrm{mg} \mathrm{P}$ per plant, corresponding to $58 \% \mathrm{P}$ increase over the control.

Absorption and accumulation of the other nutrients in response to the treatments compared with the control (control versus Factorial) was also significant, with 22, 20, 29 and $51 \%$ increases for $\mathrm{N}, \mathrm{K}, \mathrm{Ca}$ and $\mathrm{Mg}$ respectively. Again, on average, the citric acid significantly increased nutrient absorption, with 28, 28, 36 and $61 \%$ increase for $\mathrm{N}, \mathrm{K}, \mathrm{Ca}$ and $\mathrm{Mg}$ respectively, compared with the control (control versus $\mathrm{NF}+\mathrm{HA}+$ CA).

Similar to what was found for production of DM of aerial parts, the response curves for $\mathrm{P}$ contents in different concentrations of humic acids, combined or not with citric acid, resulted in different concentrations for determination of the maximum point of the regression functions (Table $10)$.

The maximum $\mathrm{P}$ accumulation points in response to the concentration of humic acids combined with rock phosphate were 20.8 and $9.1 \mathrm{mmol} \mathrm{L}^{-1}$ of $\mathrm{C}$ in the form of humic acids, with and without citric acid, respectively. These values are very close to 18.8 and 9.3 mmol L $\mathrm{L}^{-1}$ of $\mathrm{C}$ of maximum production of DM of aerial parts in response to the same treatments (Table 11). The maximum $P$ contents were 8.39 and $12.37 \mathrm{mg}$ per plant for the concentrations of humic acids, with and without citric acid, respectively. Thus, citric acid promoted a $47 \%$ increase in $\mathrm{P}$ content in the condition of maximum efficiency.

The same behavior was observed for the contents of the other nutrients. At the point of maximum dry matter, the combination of natural phosphate with humic acids and citric acid gave higher values than those obtained for the use of natural phosphate with humic acids alone (Table 11). 
Table 8. Nutrient contents in the aerial part of pineapple cv. Pérola in response to application of rock phosphate combined or not with humic acids, with or without citric acid

\begin{tabular}{lccccc}
\hline & \multicolumn{6}{c}{ Nutrient contents in the aerial part ${ }^{(2)}$} \\
\cline { 2 - 5 } Treatment $^{(1)}$ & $\mathbf{N}$ & $\mathbf{P}$ & $\mathbf{K}$ & $\mathbf{C a}$ & $\mathbf{M g}$ \\
\cline { 2 - 5 } & \multicolumn{7}{c}{$\mathrm{mg} /$ plant } \\
\hline$(-)$ & 104.15 & 7.13 & 176.55 & 26.85 & 12.60 \\
NF & 126.08 & 10.14 & 195.98 & 36.48 & 17.12 \\
NF+HA(10) & 119.14 & 9.76 & 211.15 & 32.48 & 16.52 \\
NF+HA(20) & 108.21 & 7.67 & 189.06 & 34.19 & 19.78 \\
NF+HA(40) & 136.34 & 10.12 & 205.92 & 29.28 & 19.11 \\
NF+HA(10)+CA & 146.68 & 12.65 & 257.87 & 39.86 & 23.34 \\
NF+HA(20)+CA & 138.88 & 11.42 & 225.68 & 39.22 & 21.48 \\
NF+HA(40)+CA & 112.95 & 9.71 & 194.81 & 30.22 & 15.98 \\
Mean NF+HA & 121.23 & 9.18 & 202.04 & 31.98 & 18.47 \\
Mean NF+HA+CA & 132.84 & 11.26 & 226.12 & 36.43 & 20.26 \\
\hline
\end{tabular}

(1) Treatments: $(-)=$ control; $\mathrm{NF}=$ Araxá rock phosphate; $\mathrm{HA} \mathrm{(10)}=$ vermicompost-derived humic acids at $10 \mathrm{mmol} \mathrm{L}^{-1}$ of $\mathrm{C} ; \mathrm{HA}(20)=$ vermicompost-derived humic acids at $20 \mathrm{mmol} \mathrm{L}^{-1}$ of C; $\mathrm{HA}(40)=$ vermicompost-derived humic acids at $40 \mathrm{mmol} \mathrm{L}^{-1}$ of C; $\mathrm{CA}=$ citric acid. ${ }^{(2)}$ Contents: $\mathrm{N}, \mathrm{P}, \mathrm{K}, \mathrm{Ca}$ and $\mathrm{Mg}=$ nitrogen, phosphorus, potassium, calcium and magnesium, respectively.

Table 9. Mean contrasts, relative increments, mean square error (MSE) and coefficient of variation (CV) for nutrient contents of the aerial part of pineapple cv. Pérola in response to application of rock phosphate combined or not with humic acids, with or without citric acid

\begin{tabular}{|c|c|c|c|c|c|c|}
\hline \multirow{3}{*}{ Comparison $^{(1)}$} & \multirow{3}{*}{ D. F. } & \multicolumn{5}{|c|}{ Mean contrasts for nutrient contents ${ }^{(2)}\left(\right.$ Relative increments $\left.^{(3)}\right)$} \\
\hline & & $\mathbf{N}$ & $\mathbf{P}$ & $\mathbf{K}$ & Ca & $\mathrm{Mg}$ \\
\hline & & \multicolumn{4}{|c|}{$\mathrm{mg} / \mathrm{plant}$} & \\
\hline (-) vs. Factorial & 1 & $\begin{array}{r}22.75^{\circ} \\
(22)\end{array}$ & $\begin{array}{c}3.09 * * \\
(43)\end{array}$ & $\begin{array}{r}34.95^{\circ} \\
(20)\end{array}$ & $\begin{array}{r}7.69^{\circ} \\
(29)\end{array}$ & $\begin{array}{c}6.44^{*} \\
(51)\end{array}$ \\
\hline$(-)$ vs. NF & 1 & $\begin{array}{r}21.93 \\
(21)\end{array}$ & $\begin{array}{r}3.02 * \\
(42)\end{array}$ & $\begin{array}{r}19.43 \\
(11)\end{array}$ & $\begin{array}{l}9.63 \\
(36)\end{array}$ & $\begin{array}{c}4.51 \\
(36)\end{array}$ \\
\hline (-) vs. NF+HA & 1 & $\begin{array}{r}17.08 \\
(16)\end{array}$ & $\begin{array}{r}2.06^{\circ} \\
(29)\end{array}$ & $\begin{array}{r}25.50 \\
(14)\end{array}$ & $\begin{array}{l}5.14 \\
(19)\end{array}$ & $\begin{array}{r}5.86^{\circ} \\
(47)\end{array}$ \\
\hline$(-)$ vs. $\mathrm{NF}+\mathrm{HA}+\mathrm{AC}$ & 1 & $\begin{array}{r}28.69^{*} \\
(28)\end{array}$ & $\begin{array}{c}4.14 * * \\
(58)\end{array}$ & $\begin{array}{r}49.57^{\circ} \\
(28)\end{array}$ & $\begin{array}{r}9.59^{\circ} \\
(36)\end{array}$ & $\begin{array}{c}7.66^{*} \\
(61)\end{array}$ \\
\hline $\mathrm{NF}$ vs. $\mathrm{NF}+\mathrm{HA}$ & 1 & $\begin{array}{r}-4.85 \\
(4)\end{array}$ & $\begin{array}{r}-0.96 \\
(10)\end{array}$ & $\begin{array}{r}6.07 \\
(3)\end{array}$ & $\begin{array}{r}-4.49 \\
(14)\end{array}$ & $\begin{array}{r}1.35 \\
(8)\end{array}$ \\
\hline $\mathrm{NF}$ vs. $\mathrm{NF}+\mathrm{HA}+\mathrm{CA}$ & 1 & $\begin{array}{r}6.76 \\
(5)\end{array}$ & $\begin{array}{r}1.12^{\circ} \\
(11)\end{array}$ & $\begin{array}{r}30.14 \\
(15)\end{array}$ & $\begin{array}{r}-0.04 \\
(0)\end{array}$ & $\begin{array}{c}3.15 \\
(18)\end{array}$ \\
\hline $\mathrm{NF}+\mathrm{HA}$ vs. $\mathrm{NF}+\mathrm{HA}+\mathrm{CA}$ & 1 & $\begin{array}{r}11.61 \\
(10)\end{array}$ & $\begin{array}{c}2.08^{*} \\
(23)\end{array}$ & $\begin{array}{r}24.07 \\
(12)\end{array}$ & $\begin{array}{c}4.45 \\
(14)\end{array}$ & $\begin{array}{r}1.80 \\
(10)\end{array}$ \\
\hline MSE & 38 & 796.82 & 6.69 & 2.072 .25 & 106.77 & 38.64 \\
\hline C.V. $(\%)$ & & 22.76 & 26.32 & 21.98 & 30.78 & 34.08 \\
\hline
\end{tabular}

(1) Comparison: $(-)$ = control; $\mathrm{HA}=$ vermicompost-derived humic acids; $\mathrm{CA}=$ citric acid; and $\mathrm{NF}=$ rock phosphate. ${ }^{(2)}$ Effects on nutrient content: $\mathrm{N}, \mathrm{P}, \mathrm{K}, \mathrm{Ca}$ and $\mathrm{Mg}=$ nitrogen, phosphorus, potassium, calcium and magnesium, respectively. ${ }^{(3)}$ Relative increments: $100(\mathrm{x}-\mathrm{y}) /$ $\mathrm{y}$, where $\mathrm{x}=$ mean of treatment with the highest value and $\mathrm{y}=$ mean of treatment with the lowest value. ${ }^{\circ}, *$ and $* *=$ significant at 10,5 and $1 \%$ probability levels, respectively.

Table 10. Regression equations for nutrient content (mg/plant) of the aerial part of pineapple cv. Pérola as a function of concentrations of humic acids (HA) combined with rock phosphate (NF), with or without citric acid (CA)

\begin{tabular}{lccc}
\hline Variable $^{(1)}$ & Decomposition $^{(2)}$ & Regression equation & $\mathbf{R}^{2}$ \\
\hline $\mathrm{N}$ & $\mathrm{NF}+\mathrm{HA}$ & $\hat{\mathrm{y}}=127.77-1.82 \mathrm{x}+0.0505^{(\mathrm{P}<0.12)} \mathrm{x}^{2}$ & 0.917 \\
& $\mathrm{NF}+\mathrm{HA}+\mathrm{CA}$ & $\hat{\mathrm{y}}=127.11+14.99^{\circ} \mathrm{x}^{0.5}-2.70 \mathrm{x}$ & 0.999 \\
$\mathrm{P}$ & $\mathrm{NF}+\mathrm{HA}$ & $\hat{\mathrm{y}}=10.46-0.20 \mathrm{x}+0.0048^{(\mathrm{P}<0.11)} \mathrm{x}^{2}$ & 0.700 \\
\hline
\end{tabular}

(1) Variable: $\mathrm{N}, \mathrm{P}, \mathrm{K}, \mathrm{Ca}$ and $\mathrm{Mg}=$ nitrogen, phosphorus, potassium, calcium and magnesium contents, respectively. ${ }^{(2)}$ Decomposition: $\mathrm{NF}=$ rock phosphate; HA = vermicompostderived humic acids; $\mathrm{CA}=$ citric acid, and ${ }^{(\mathrm{P})},{ }^{\circ}$ and $*$ = significant at $\mathrm{P}, 10$ and $5 \%$ probability levels, respectively. 
Table 11. Values of nutritional composition of the aerial part of pineapple cv. Pérola for the treatments rock phosphate combined with humic acids, with citric acid (NF $+\mathrm{HA})$ or without citric acid (NF + HA + CA), based on the concentration of maximum physical efficiency (MPE)

\begin{tabular}{lcc}
\hline \multirow{2}{*}{ Nutrient } & \multicolumn{2}{c}{ Values for the MPE concentration ${ }^{(\mathbf{1})}$} \\
\cline { 2 - 3 } & \multicolumn{1}{c}{ NF+HA } & NF+HA+CA \\
\cline { 2 - 3 } & \multicolumn{1}{c}{ mg/plant } \\
\hline $\mathrm{N}$ & 111.40 & 147.71 \\
$\mathrm{P}$ & 8.39 & 12.37 \\
$\mathrm{~K}$ & 200.53 & 248.02 \\
$\mathrm{Ca}$ & 32.92 & 39.48 \\
$\mathrm{Mg}$ & 18.13 & 23.15 \\
\hline
\end{tabular}

(1) Generated by the first derivative of the regression equation for dry matter.

\section{DISCUSSION}

The best growth performance and nutritional status of pineapple plants occurred in the following order of treatments: control < rock phosphate $\sim$ rock phosphate with humic acids < rock phosphate combined with humic acids and citric acid. The isolated use of rock phosphate resulted in a better initial performance when compared with the control. We can conclude, therefore, that the portion of phosphate accumulated with application of rock phosphate alone was inferior to that obtained when it was combined with organic acids. Thus the increase in $\mathrm{P}$ contents, alongside higher growth and higher mass of pineapple plants found for the combination of phosphate with humic acids, especially in the presence of citric acid, resulted in greater absorption and accumulation of this nutrient. Such utilization can be attributed to increased $\mathrm{P}$ solubility when applied together with organic acids. It is assumed that this increased solubilization may be caused by:

i) the proton supply by organic acids;

ii) the complexation of $\mathrm{Ca}^{2+}$ by organic ligands; and

iii) the physiological stimulus of plants, i.e., the bioactivity of humic acids, which may have increased the efficiency of plant $\mathrm{P}$ transporters.

The following reaction represents the acid dissolution of fluorapatite:

$$
\mathrm{Ca}_{10}\left(\mathrm{PO}_{4}\right)_{6} \mathrm{~F}_{2}(\mathrm{~s})+12 \mathrm{H}^{+}(\mathrm{aq})=10 \mathrm{Ca}^{2+}(\mathrm{aq})+6 \mathrm{H}_{2} \mathrm{PO}_{4}^{-}
$$
(aq) $+2 \mathrm{~F}^{-}$(aq.) (Equation 1)

Equation 1 shows the $\mathrm{P}$ solubilization from rock phosphate based on items $\mathrm{i}$ and ii above. In the equation, proton consumption and $\mathrm{Ca}^{2+}$ solubilization can be related to the acidity of humic acids' functional groups and, simultaneously, by cation exchange, to the complexation on the surface of $\mathrm{Ca}^{2+}$ solubilized by the negatively charged ligand derived from the dissociation. Equation 2 exemplifies this exchange/complexation reaction:

$\mathrm{SH}_{2}(\mathrm{~s} / \mathrm{aq})+\mathrm{Ca}^{2+}(\mathrm{aq})=\mathrm{S}_{2} \mathrm{Ca}(\mathrm{s} / \mathrm{aq})+2 \mathrm{H}^{+}$(aq.) (Equation 2), where $\mathrm{S}$ represents two moles of charge of the organic acids' functional group. Overall, in this study, carboxyl functional groups tend to predominate as sources of protons in both the organic acids added and those that may have been exuded by plants. The $\mathrm{pK}$ values for these functional groups are consistent with the expected dissociation under the experimental conditions of this study.

Observing the equations 1 and 2, we can see that protons are reactants and $\mathrm{Ca}^{2+}$ is a product, that is, the removal of $\mathrm{Ca}^{2+}$ by complexation with the ligand and the proton ionization are simultaneous and, according to Sposito (2008), occur rapidly. Thus, these facts are in accordance with the argument in iii, since, when stimulated, the plants tend to absorb more $\mathrm{P}$ and $\mathrm{Ca}$, and hence, by removing products, the solubilization of the remaining rock phosphate increases. Cation absorption stimulates extrusion of $\mathrm{H}^{+}$, increasing the reagent acidity in Equation 1.

It is expected that, by the same mechanism of stimulation attributed to humic acids, namely, activation of cation uptake and extrusion of protons (acidity growth), the treatments resulted in additional increases in P solubility. Additionally, the efficiency of $\mathrm{P}$ transporters could have increased, resulting in increased uptake by plants (Canellas et al. 2002; Canellas \& Façanha, 2004; Canellas et al. 2006; Canellas et al. 2008; Zandonadi et al., 2007).

According to the above discussed, the addition of low concentrations of organic acids tend to diversify and increase the activity of humic acids' components in solution. This therefore leads to an enhanced acid, complexing and biostimulating strength of humic acids and hence explain the positive effect of low concentrations of citric acid $\left(0.005 \mathrm{mmol} \mathrm{L}^{-1}\right)$ combined with humic acids on $\mathrm{P}$ solubility, resulting in increased accumulation of $\mathrm{P}$ and dry matter in plants. Canellas et al. (2008b) reported that the presence of citric acid, as well as malic, tartaric and oxalic acids, occurred and/or increased in the exudates of maize roots in response to concentrations of humic acids.

Finally, the combination organic acids and natural phosphate resulted in increased $\mathrm{P}$ utilization, better nutritional composition and growth of plants, and consequently superior initial performance of pineapple. This behavior favors plant establishment (a critical physiological stage in this crop) and confer greater fitness in the subsequent growth conditions by increasing reserves and possibilities of water and nutrient uptake and light capture. 


\section{CONCLUSION}

The application of rock phosphate combined with vermicompost-derived humic acids $\left(9.3 \mathrm{mmol} \mathrm{L}^{-1}\right.$ of C) and citric acid $\left(0.005 \mathrm{mmol} \mathrm{L}^{-1}\right)$ to basal leaf axils of pineapple cv. Pérola increased N, P, K, Ca and Mg leaf contents and growth of aerial parts, resulting in better initial performance of pineapple plants.

\section{ACKNOWLEDGEMENTS}

We would like to thank to FAPERJ, for the financial support (E-26/110.633/2007); PIBIC/CNPq/UENF for the scientific initiation scholarship granted to the research; Prof. Pedro Henrique Monerat (UENF) for the assistance in conducting the nutritional analyses and to Dr. Jader Galba Busato (UnB) for the suggestions and the supply of Araxá rock phosphate.

\section{REFERENCES}

Alvarez V., V.H. \& Alvarez, G.A.M. (2006) Comparações de médias ou testes de hipóteses? Contrastes! Boletim Informativo da Sociedade Brasileira de Ciência do Solo, 31:24-34.

Baldotto, M.A.; Canellas, L.P.; Canela M.C.; Simões M.L.; MartinNeto, L.; Fontes, M.P.F. \& Velloso A.C.X. (2007) Propriedades redox e grupos funcionais de ácidos húmicos isolados de adubos orgânicos. Revista Brasileira de Ciência do Solo, 31:465-475.

Baldotto, L.E.B.; Baldotto, M.A.; Giro, V.B.; Canellas, L.P.; Olivares, F.L. \& Bressan-Smith, R. (2009) Desempenho do abacaxizeiro 'Vitória' em resposta à aplicação de ácidos húmicos durante a aclimatação. Revista Brasileira de Ciência do Solo, 33:979-990.

Busato, J. G.; Velloso, A.C.X.; Canellas, L. P.; Cabral, L. L. (2005) Solubilização de fosfatos naturais de rocha em resposta ao tratamento com ácidos húmicos. In: Encontro Brasilerio de Substâncias Húmicas, Rio de Janeiro, Anais, UFRRJ/Embrapa CNPS.

Canellas, L.P.; Façanha, A.O.; Façanha, A.R. \& Olivares, F.L. (2002) Humic acids isolated from earthworm induces root mitotic sites and plasma membrane $\mathrm{H}^{+}$-ATPase. Plant Physiology, 30:1951-1957.

Canellas, L.P. \& Façanha, A.R. (2004) Relantionship between chemical nature of soil humifield fractions and their bioactivity. Pesquisa Agropecuária Brasileira, 39:233- 240.

Canellas, L.P.; Zandonadi, D.B.; Olivares, F.L. \& Façanha, A.R. (2006) Efeitos fisiológicos de substâncias húmicas - o estímulo às $\mathrm{H}^{+}$ATPases. In: Fernandes, M.S. (Eds.) Nutrição Mineral de Plantas. v.1. Viçosa, Sociedade Brasileira de Ciência do Solo. p.175-200.

Canellas, L.P.; Zandonadi, D.B.; Busato, J.G.; Baldotto, M.A.; Simões, M.L.; Martin-Neto, L.; Façanha, A.R.; Spaccini, R. \& Piccolo, A. (2008a) Bioactivity and chemical characteristics of humic acids from tropical soils sequence. Soil Science, 173:1-14.

Canellas, L.P.; Teixeira Junior, L.R.L.; Dobbss, L.; Silva, C.A.; Medici, L.O.; Zandonadi, D.B. \& Façanha, A.R. (2008b) Humic acids cross interactions with root and organic acids. Annals of Applied Biology, 1:1-10

Empresa Brasileira de Pesquisa Agropecuária - EMBRAPA (1980) I Reunião de Classificação e Correlação de Solos do Estado do Rio de Janeiro: Serviço Nacional de Levantamento e Conservação de Solos. 79p. (EMBRAPA-SNLCS. Boletim Técnico, 62).
FAO. Disponível em: < http://www.faostat.fao.org >. Acessado em 08 dezembro 2010.

Giro, V. B. (2008a). Desempenho inicial do abacaxizeiro em resposta à adubação com fosfato natural de Araxá combinada com ácidos húmicos e ácido cítrico na axila foliar. Monografia de Conclusão de Curso em Agronomia. Universidade Estadual do Norte Fluminense Darcy Ribeiro. Campos dos Goytacazes, 47p.

Giro, V. B. (2008b). Desempenho do abacaxizeiro em resposta à adubação fosfatada combinada com substâncias húmicas e ácidos orgânicos na axila foliar. Relatório de Iniciação Científica (PIBIC-CNPq). Universidade Estadual do Norte Fluminense Darcy Ribeiro. Campos dos Goytacazes, 36p.

Leal, J.R. \& Velloso, A.C.X. (1973) Adsorção de fosfato em Latossolo sob vegetação de cerrado. Pesquisa Agropecuária Brasileira, 8:89- 92 .

Kpomblekou, K. \& Tabatabai, M.A. (2003) Effect of low molecular weight organic acids on phosphorus release and phytoavailability of phosphorus in phosphate rocks added to soils. Agriculture, Ecosystems and Environmental, 100:275-284.

Nardi, S.; Pizzeghello, D.; Muscolo, A. \& Vianello, A. (2002) Physiological effects of humic substances in higher plants. Soil Biology and Biochemistry, 34:1527-1537.

Novais, R.F.; Neves, J.C.L. \& Barros, N.F. (1991) Ensaios em ambiente controlado. In: Empresa Brasileira de Pesquisa Agropecuária - Embrapa (Ed.) Métodos de pesquisa em ambiente controlado. 1. ed. Brasília, Embrapa Produção de Informação. 392p.

Novais, R.F. \& Smyth, T.J. (1999) Fósforo em solo e planta em condições tropicais. 1. ed. Viçosa, UFV. 399p.

Piccolo, A.; Nardi, S. \& Concheri, G. (1996a) Macromolecular changes of humic substances induced by interactions with organic acids. European Journal of Soil Science, 47:319-328.

Piccolo, A.; Nardi, S. \& Concheri, G. (1996b) Micelle-like conformation of humic substances as reveled by size exclusion chromatography. Chemosphere, 33:595-602.

Piccolo, A. (2001) The supramolecular structure of humic substances. Soil Science, 166:810-832.

Ramos, M.J.M. (2006) Caracterização e sintomas de deficiência de macronutrientes e de boro em abacaxizeiro cultivar Imperial. Tese (Doutorado em produção Vegetal), Universidade estadual do Norte Fluminense Darcy Ribeiro, Campos dos Goytacazes, RJ. 95p.

Simpson, A.J., Burdon, J., Graham, C.L., Hayes, M.H.B., Spencer, N. \& Kingery, W.L. (2001) Interpretation of heteronuclear and multidimensional NMR spectroscopy of humic substances. European Journal of Soil Science, 52:495-510.

Sposito, G. (2008) The chemistry of soils. 2. ed. New York: University Oxford Press. 329p.

Steel, R.G.D., Torrie, J.H. (1960) Principles and procedures of statistics with special reference to the biological sciences. McGraw-Hill Book Company, New York, 453p.

Teixeira, L.A.J.; Spironello, A.; Furlani, P.R. \& Sigrist, J.M.M. (2002) Parcelamento da adubação NPK em abacaxizeiro. Revista Brasileira de Fruticultura, 24:219-224.

Zandonadi, D.B. (2006) Bioatividade de substâncias húmicas: promoção do desenvolvimento radicular e atividade das bombas de $\mathrm{H}^{+}$. Dissertação de Mestrado. Universidade Estadual do Norte Fluminense Darcy Ribeiro. Campos dos Goytacazes. 173p.

Zandonadi, D.B.; Canellas, L.P. \& Façanha, A.R. (2007) Indolacetic and humic acids induce lateral root development through a concerted plasmalemma and tonoplast $\mathrm{H}^{+}$pumps activation. Planta, 225:1583-1595. 